\title{
PROBLEMS IN THE STRENGTH AND STABILITY OF INHOMOGENEOUS STRUCTURES OF ROCKET AND SPACE HARDWARE WITH ACCOUNT FOR PLASTICITY AND CREEP
}

\author{
${ }^{1}$ Institute of Technical Mechanics \\ of the National Academy of Sciences of U kraine and the State Space Agency of U kraine \\ 15 Leshko-Popel St., Dnipro 49005, Ukraine; e-mail: hudramovich@i.ua \\ ${ }^{2}$ Yuzhnoye State Design Office \\ 3 Kryvorizka St. D nipro 49008, U kraine e-mail: v.n.sirenko@ukr.net \\ ${ }^{3}$ Oles Honchar D nipro National University \\ 72 Haharina Ave., Dnipro 49010, Ukraine; e-mail: hart@ua.fm
}

\begin{abstract}
Shell structures provide a compromise between strength and mass, which motivates their use in rocket and space hardware (RSH). High and long-term loads cause plastic and creep deformations in structural elements. RSH structures feature inhomogeneity: design inhomogeneity (polythickness, the presence of reinforcements, openings, etc.) and technological inhomogeneity (defects produced in manufacturing, operation, storage. and transportation, defects produced by unforeseen thermomechanical effects, etc.). These factors, which characterize structural inhomogeneity, are stress and strain concentrators and may be responsible for an early failure of structural elements and inadmissible shape imperfections. In inhomogeneous structures, different parts thereof are deformed by a program of their own and exhibit a different stress and strain level. In accounting for a physical nonlinearity, which is governed by plastic and creep deformations, the following approach to the determination of the stress and strain field is efficient: the calculation is divided into stages, and at each stage parameters that characterize the plastic and creep deformations developed are introduced: additional loads in the equilibrium equations or boundary conditions, additional deformations, or variable elasticity parameters (the modulus of elasticity and Poisson's ratio). Successive approximation schemes are constructed: at each stage, an elasticity problem is solved with the introduction of the above parameters. Special consideration is given to the determination of the launch vehicle and launch complex life. This is due to damages caused by alternate high-intensity thermomechanical loads. The basic approach relies on the theory of low- and high-cycle fatigue. The plasticity and the creep of a material are the basic factors in the consideration of the above problems. This paper considers various aspects of the solution of RSH strength and stability problems with account for the effect of plastic and creep deformations.
\end{abstract}

Keywords stress and strain field, strength, stability, plasticity, creep.

1. Il'yushin A. A. Works in 4 volumes. V. 2. Plasticity. Moscow, 2004. 408 pp. (in Russian).

2. Ishlinsky A. Yu., Ivlev D. D. Mathematical Theory of Plasticity. Moscow, 2001. 700 pp. (in Russian).

3. Hutchinson J. W. Plastic buckling. Advances in Appl. Mech. 1974. V. 14. Pp. 67-144. https://doi.org/10.1016/S0065-2156(08)70031-0

4. Hudramovich V. S. Stability of Elastoplastic Shells. Kiev, 1987. 216 pp. (in Russian).

5. Parton V. Z., Morozov E. M. Mechanics of Elastoplastic Failure. Moscow, 1985. 504 pp. 
(in Russian).

6. Tomsen E., Yang Ch., Kobayashi Sh. Mechanics of Plastic Deformations in Metal Working. Moscow, 1968. 504 pp. (in Russian).

7. Mossakovsky V. I., Hudramovich V. S., Makeev E. M. Contact Interactions of Shell Structure Elements. Kiev, 1988. 288 pp. (in Russian).

8. Hudramovych V. S. Contact mechanics of shell structures under local loading. Int. Appl. Mech. 2009. V. 45. No. 7. Pp. 708-729.

https://doi.org/10.1007/s10778-009-0224-5

9. Il'yushin A. A. Works in 4 volumes. V. 4. Simulation of Dynamic Processes in Solids and Engineering Applications. Moscow, 2009. 526 pp. (in Russian).

10. Hudramovich V. S. Plastic Buckling of a finite-length cylindrical shell under local impulse loading. Theory of Shells and Plates. Proceedings of the 8th All-Union Conference on the Theory of Shells and Plates (Rostov-on-Don, 1971). Moscow, 1973. Pp. 125-130. (in Russian).

11. Velichkin V. A., Hudramovych V. S., Pilipenko V. V, et al. Oscillations of a system with physically nonlinear characteristics. Reliability of Engineering Systems under Impulse Loading. V. I. Mossakovsky (Ed.). Kiev, 1981. Pp. 4-10. (in Russian).

12. Nonlinear Models of and Problems of Deformable Solid Mechanics. Collected volume dedicated to Yu. N. Rabotnov's 70th birthday anniversary. K. V. Frolov (Ed.). Moscow, 1984. 210 pp. (in Russian).

13. Rabotnov Yu. N. Problems in Deformable Solid Mechanics. Selected works. K. V. Frolov (Ed.). Moscow, 1991. 196 pp. (in Russian).

14. Hudramovich V. S. Creep Theory and its Applications to the Analysis of Thin-Walled 
Structure Elements. Kyiv, 2005. 224 pp. (in Russian).

15. Hudramovych V. S., Hart E. L., Ryabokon' S. A. Plastic deformation of nonhomogeneous plates. J. Math. Eng. 2013. V. 78, Iss. 1. Pp. 181-197. https://doi.org/10.1007/s10665-010-9409-5

16. Hart E. L., Hudramovych V. S. Applications of the projective-iterative versions of FEM in damage problems for engineering structures. Maintenance 2012. Proceedings of 2nd Int. Conf. (Zenica, Bosnia and Herzegovina, 2012). Zenica, 2012. Pp. 157-164.

17. Hart E. L., Hudramovych V. S. Projection-iterative modification of the method of local variations for problems with a quadratic functional. J. Appl. Math. and Mechanics. 2016. V. 80, Iss. 2. Pp. 158-163.

https://doi.org/10.1016/j.jappmathmech.2016.06.005

18. Hudramovich V. S., Hart E. L Finite-element analysis of the proses of scattered failure of plane-strain elestoplastic media with local stress concentrators. Elasticity and Nonelasticity. Proceedings of the International Symposium on Problems in Deformable Solid Mechanics dedicated to A. A. Il'yushin' 105th Birthday Anniversary (Moscow, January 2016). Moscow, 2016. Pp. 158-161. (in Russian).

19. Lazarev T. V., Sirenko V. N., Degtyarev M. A. et al. High-performance computing system for Yuzhnoye State Design Office' computational problems. Rocket Engineering. New Possibilities. A. V. Degtyarev (Ed.). Dnipro, 2019. Pp. 407 - 419. (in Russian).

20. Sirenko V. O. On the possibility of virtual tests in the development of rocket and space hardware to determine bearing properties. Topical Problems in Continua Mechanics and Structural Strength. Abstracts of the 2nd International Scientific and Technical Conference in memory of Acad. V. I. Mossakovsky (to his 100th birthday anniversary). (Dnipro, 2019). Dnipro, 2019. Pp. 43-44. (in Russian).

21. Degtyarev A. V. (Ed.). Sixty Years in Rocket Production and Cosmonautics. Dnipropetrovsk, 2014. 540 pp. (in Russian). 
22. McEvily A. J. Accident-Causing Failure Analysis. Moscow, 2010. 416 pp. (in Russian).

23. Song Z. Test and launch control technology for launch vehicles. Singapore: Springer, 2018. 256 pp.

https://doi.org/10.1007/978-981-10-8712-7

24. Hudramovich V. S., Sirenko V. N., Klimenko D. V., Daniev Ju. F., Hart E. L.

Development of the normative framework methodology for justifying the launcher structures resource of launch vehicles. Strength of Materials. 2019. V. 51, No. 3. Pp. 333-340.

https://doi.org/10.1007/s11223-019-00079-4

25. Hudramovych V. S. Features of nonlinear deformation of shell systems with geometrical imperfections. Int. Appl. Mech. 2006. V. 42, No. 7. p. 3-37.

https://doi.org/10.1007/s10778-006-0204-y

26. Hudramovich V. S. Critical states of inelastic shells under complex loading. Stability in Deformable Solid Mechanics. Proceedings of the All-Union Symposium (Kalinin, 1981). V. G. Zubchaninov (Ed.). Kalinin, 1981. Pp. 61-87. (in Russian).

27. Hudramovich V. S. Stability and bearing capacity of plastic shells. Structural Strength and Durability. V. S. Budnik (Ed.). iev, 1980. Pp. 15-32. (in Russian).

28. Hudramovich V. S., Pereverzev E. S. Bearing Capacity and Durability of Structural Elements. Kiev, 1981. 284 pp. (in Russian).

29. Hudramovich V. S., Demenkov A. F., Konyukhov S. N. Bearing capacity of nonideal cylindrical shells with account for plastic deformations. Structural Strength and Reliability. V. S. Budnik (Ed.). Kiev, 1982. Pp. 45-48. (in Russian).

30. Hudramovich V. S., Konovalenkov V. S. Deformation and limiting state of inelastic shells with account for loading history. Izvestiya AN SSSR. Mekhanika Tverdogo Tela. 1987. No. 3. Pp 157-163. (in Russian). 
31. udramovich V. S. Plastic and creep instability of shells with initial imperfections. Solid Mechanics and Its Applications. V. 64. G. M. L. Gladwell (Ed.). Dordrecht, Boston, London, 1997. Pp. 277-289.

https://doi.org/10.1007/0-306-46937-5 23

32. udramovich V. S., Lebedev A. A., Mossakovsky V. I. Plastic deformation and limit states of metal shell structures with initial shape imperfections. Light-Weight Steel and Aluminium Structures: Proceedings Int. Conf. (Helsinki, Finland, 1999), P. Makelainen (Ed.). Amsterdam, Lousanne, New York, Tokyo, 1999. Pp. 257-263.

https://doi.org/10.1016/B978-008043014-0/50133-5

33. Kushnir R. M., Nykolyshyn M. M., Osadchuk V. A. Elastic and Elastoplastic Limiting State of Shells with Defects. Lviv, 2003. 320 pp. (in Ukrainian).

34. udramovich V. S. Limit analysis: an efficient method to estimate the structural strength of shell systems. Proceedings of the International Conference: Material Failure Mechanics and Structural Strength (Lviv, 2003). V. V. Panasiuk (Ed.). Lviv, 2003. Pp. 583-588. (in Russian).

35. udramovich V. S., Gerasimov V. P., Demenkov A. F. Limit Analysis of Structural Elements. Kiev, 1990. 136 pp. (in Russian).

36. Gerasimov V. P., udramovich V. S., Larionov I. F. Et al. Plastic failure of composite shell structures in axial compression. Problemy Prochnosti. 1979. No. 11. Pp. 58-61. (in Russian). https://doi.org/10.1007/BF00767054

37. Drucker D. Microscopic Foundations of Brittle Failure Theory. V. 1. Failure. Moscow, 1973. Pp. 505-569. (in Russian).

38. Galkin V. F., udramovich V. S., Mossakovsky V. I., Spiridonov I. N. On the effect of the yield point on the stability of cylindrical shells in axial compression. Izvestiya AN SSSR. Mekhanika Tverdogo Tela. 1973. No. 3. Pp.180-182. (in Russian).

39. udramovich V. S., Dzyuba A. P., Selivanov Yu. M. Holographic Interferometry 
Methods in the Mechanics of Inhomogeneous Thin-Walled Structures. Dnipro, 2017. 288 pp. (in Russian).

40. udramovich V. S., Skalskyi V. P., Selivanov Yu. M. Holographic and AcousticEmissive Diagnostics of Inhomogeneous Structures and Materials. Lviv, 2017. 488 pp. (in Ukrainian).

41. Pisarenko G. S., Strizhalo V. A. Experimental Methods in Deformable Solid Mechanics. Kyiv, 2018. 242 pp. (in Russian).

42. Guz' A. N., Dyshel' M. Sh., Kuliev G. G., Milovanova O. B. Failure and Local Loss of Stability of Thin-Walled Bodies with Cutouts. Kiev, 1981. 184 pp. (in Russian). https://doi.org/10.1007/BF00884086

43. udramovich V. S., Diskovsky I. A., Makeev E. M. Thin-Walled Elements of Mirror Antennas. Kiev, 1986. 152 pp. (in Russian).

44. Hudramovich V. S., Hart E. L., Klimenko D. V., Ryabokon' S. A. Mutual influence of openings on strength of shell-type structures under plastic deformation. Strength of Materials. 2013. V. 45. Iss. 1. Pp. 1-9.

https://doi.org/10.1007/s11223-013-9426-5

45. Hudramovich V. S. Effect of openings on the limiting state of elements of thin-walled shell-and-plate metal structures. Visnyk DNU. Mekhanika. 2014. Iss. 18. V. 2. Pp. 47-65. (in Russian).

46. Dziuba A. P., Prokopalo Ye. F., Dziuba P. A. Bearing Capacity of Cylindrical Shells with Openings. Dnipro, 2014. 224 pp. (in Ukrainian).

47. Hudramovich V. S., Klymenko D. V., Hart E. L. Influence of cutouts on strength of cylindrical compartments of launch vehicles at inelastic deformation of material. Space Sci. \& Technol. 2017. V. 23. No. 6. Pp. 12-20. (in Russian). https://doi.org/10.15407/knit2017.06.012 
48. Hart E. L., Hudramovich V. S. Projection-iteration schemes of variational-grid methods in problems of elastoplastic deformation of inhomogeneous thin-walled structures. Matematychni metody ta Fizyko-Mekhanichni Polia. 2019. V. 51. No. 3. Pp. 24-39. (in Ukrainian).

49. Nikitin P. I., Hudramovich V. S., Larionov I. F. Shell stability in creep. Creep in Structures. Abstracts of the All-Union Symposium. (Dnepropetrovsk, 1982). Dnepropetrovsk, 1982. Pp. 3-5. (in Russian).

50. Hudramovich V. S. Review of studies in creep theory conducted at Institute of Technical Mechanics of the National Academy of Sciences of Ukraine and State Space Agency of Ukraine. Teh. Meh. 2016. No. 4. Pp. 85-89. (in Russian).

51. Hoff N. J., Jahsman W. E., Nachbar W. A. A study of creep collapse of a long circular shells under uniform external pressure. J. Aerospace Sci. 1959. V. 26. No. 10. Pp. 663-669. https://doi.org/10.2514/8.8243

52. Lokoshenko A. M. Creep and Durability of Metals. Moscow: Fizmatlit, 2016. 504 pp. (in Russian).

53. Barmin I. V. (Ed.) Technological Objects of the Ground Infrastructure of Rocket and Space Hardware. In 2 books. Moscow. Book 1, 2005. 412 pp. Book 2, 2006. 376 pp. (in Russian).

54. Makhutov N. A., Matvienko D. G., Romanov A. N. Problems in Strength, Technogeneous Safety, and Structural Material Science. Moscow, 2018. 720 pp. (in Russian).

55. Troshchenko V. T., Sosnovsky L. A. Metal and Alloy Fatigue Resistance. Handbook in 2 volumes. Kiev. 1987. V. 1. 510 pp. V. 2. 825 pp. (in Russian). 
